\title{
The Validity of Teaching Materials Oriented to Argument-Driven-Inquiry Model to Train Students' Science Literacy
}

\author{
Faridatur Rofi'ah \\ Science Education Program, \\ Postgraduate School \\ Universitas Negeri Surabaya \\ Surabaya, Indonesia
}

\author{
Tukiran \\ Department of Chemistry \\ Universitas Negeri Surabaya \\ Surabaya, Indonesia \\ tukiran@unesa.ac.id
}

\author{
Endang Susantini \\ Department of Biology \\ Universitas Negeri Surabaya \\ Surabaya, Indonesia
}

\begin{abstract}
Research related to the development of teaching materials using the Argument-Driven-Inquiry model to train Students' Science Literacy which seems not to have been done. Therefore, the purpose of this study is to produce a valid teaching materials. The developed teaching materials focused on the buffer solution matter. Teaching materials developed include lesson plan, student book, student worksheets, and science literacy tests. The Argument-Driven-Inquiry model referred to in developing teaching materials has eight steps, namely task identification; data collection and analysis; production of tentative arguments; argumentation session; compiling reports; double-blind group peer review; revised report; and explicit and reflective discussion. The science literacy trained in this study consists of six indicators. The study design used referred to the 4D Model. Data were obtained from the results of the experts' validation using a validation instrument and were subsequently analyzed using a Likert scale. Based on the assessment of experts, the materials developed have a very valid and reliable category. Thus, the materials can be ready to be used in learning with minor revision.
\end{abstract}

Keywords-Validity, Teaching Material, Argument-DrivenInquiry, Science Literacy, Buffer Solution

\section{INTRODUCTION}

Science education has great potential and strategic role in preparing quality human resources to face the era of industrialization and globalization in the 21 st century. In the process of learning science, students can develop the understanding and thinking skills needed to become a human being who is honest, critical, creative, has curiosity, always puts the evidence first, is flexible to new ideas, and cares for the environment [1]. Thus science education is expected to be able to shape learners who are literate in science (science literacy) and technology.

Measurement of science literacy is important to know not only the extent of students' understanding of scientific knowledge but also understanding of various aspects of the scientific process, as well as the ability to apply knowledge and scientific processes in real situations. The results of the measurement of science literacy by PISA in 2015 showed that the level of science literacy of Indonesian students was ranked $62^{\text {nd }}$ out of 70 countries with an average score of 403 $[2,3,4]$. This shows that only a small proportion of students have been able to identify the scientific component and use their knowledge in many complex life situations.

Graber (2001) emphasizes the need for a balance between various abilities and requires skills in decision making, where the decision-making process involves the skills of argumentation [5]. Arguments in learning science can be defined as the process of connecting claims and data and evaluating claims using empirical and theoretical evidence [6]. In arguing, students must provide evidence in the form of data and theory so that ideas that have been proposed can be accepted by others. The skill to examine and then accept or reject connections between evidence and theoretical ideas is seen as an important aspect of science literacy [7]. Therefore, it needs a learning that can further enhance students' science literacy through argumentation.

The Argument-Driven-Inquiry (ADI) model is a learning model that can teach argumentation skills. ADI models help teachers provide opportunities for students to design investigations, collect and analyze data, communicate their ideas with others during structured and interactive argumentation sessions, write investigative reports to share and document their work, and engage in peer review during laboratory investigations [8]. Students will be faced with problems that must be solved, so students will use their scientific abilities, gather information and scientific evidence to solve the problem. ADI model help to train science literacy and enable students to develop scientific thinking, provide evidence, and think critically, where the process of providing evidence is one aspect of scientific argumentation [8].

One way for teachers to train students' science literacy is to develop teaching materials. In general, teaching materials oriented to ADI model to train students' science literacy is still rare. Therefore, the researcher will develop teaching materials oriented to ADI model to train students' science literacy. The topic of the instruments is the buffer solution, that taught $11^{\text {th }}$-grade senior high school students.

\section{METHODS}

The type of research used in this study is a development study that adopted the 4D model from Thiagarajan, Semmel, and Semmel (1974) [9]. The design of the 4D model has four stages: (1) define, (2) design, (3) develop, and (4) disseminate. This study limited to develop stage because 
validation is done at this stage. The specifications of the teaching materials included a lesson plan, student book, student worksheets, and science literacy tests.

There are five main steps at the defining stage namely curriculum analysis, student analysis, task analysis, concept analysis, and formulation of learning objectives. The design stage aims to design teaching materials, including preparation of tests, selection of tools and materials, and initial design of learning, which results in draft I. At the development stage, a review and validation of the teaching materials (draft I) was carried out on the aspects of the truth of the concept/content, presentation, and language.

The validation process is carried out by chemistry lecturers. Validity data was collected using a validation technique using a validation instrument. The assessment is done using category $4=$ very good, $3=\operatorname{good}, 2=\operatorname{good}$ enough, and $1=$ not good. Validation data were analyzed descriptively quantitative. Analyzes were carried out on every aspect contained in the validation instrument. Validation data is analyzed by finding the mode of the scores given by all validators. Based on this mode is used to determine the quality of teaching materials according to the criteria in Table 1 [10].

TABLE I. TEACHING MATERIALS VALIDITY CRITERIA

\begin{tabular}{|c|c|c|}
\hline Score & Category & Explanation \\
\hline $3,6 \leq \mathrm{P} \leq 4,0$ & Very Valid & Without revision \\
\hline $2,6 \leq \mathrm{P} \leq 3,5$ & Valid & Minor revision \\
\hline $1,6 \leq \mathrm{P} \leq 2,5$ & Less Valid & Major revisions \\
\hline $1,0 \leq \mathrm{P} \leq 1,5$ & Invalid & Needs consultation \\
\hline
\end{tabular}

Based on Table 1 it can be seen that the teaching materials is said to be valid and feasible to use if it gets a minimum score of 2.6. Instrument reliability calculation which aims to find out the similarity of values given by three validators is calculated using the formula (1):

$$
\text { Percentage of Agreement }(\mathrm{PoA})=\left[1-\frac{A-\mathrm{B}}{\mathrm{B}+\mathrm{A}}\right] \times 100 \%
$$

which $\mathrm{A}$ is the highest score given by the validator and $\mathrm{B}$ is the lowest score given by the validator. The assessment of teaching materials is said to be reliable if the percentage obtained $\geq 75 \%$ [11].

\section{RESUlT AND DisCUSSION}

\section{A. Results}

1) Validation Result of Lesson Plan: A lesson plan is a guideline that is systematically designed for the implementation of learning. The lesson plan that was developed was oriented towards the ADI model which aims to train science literacy on the buffer solutions matter. The lesson plans are arranged in three meetings. The validation aspects included: format, content, suitability with ADI Model, suitability to train science literacy, and language. The validation results can be seen in Table II.
TABLE II. LESSON PLAN VALIDATION RESULT

\begin{tabular}{|l|c|c|c|}
\hline \multicolumn{1}{|c|}{ Aspects } & $\begin{array}{c}\text { Score } \\
\text { Mode }\end{array}$ & PoA (\%) & Category \\
\hline Format & 4 & 90 & Very Valid \\
\hline Content & 4 & 91 & Very Valid \\
\hline Suitability with ADI model & 4 & 96 & Very Valid \\
\hline $\begin{array}{l}\text { Suitability to train science } \\
\text { literacy }\end{array}$ & 4 & 93 & Very Valid \\
\hline Language & 3 & 86 & Valid \\
\hline
\end{tabular}

Based on Table II, the lesson plan gets a mode score between $3-4$ with the valid-very valid category. This means that the developed lesson plan can be used as a learning guide in the classroom with minor revisions. The percentage of agreement of the validation result of lesson plan gets 86$96 \%$, which is the assessment of the validators is reliable.

2) Validation Result of Student Book: The developed Student Book consists of a) concept map, b) four submersion (nature and working principle of buffer solution, buffer solution components, calculation of $\mathrm{pH}$ and capacity of buffer solution, and application of buffer solution) with sample questions and exercises, c) summary, d) comprehension practice questions, and e) bibliography. This student book is used in conjunction with student worksheets, which is to learn more about the concepts in the worksheet, specifically to formulate hypotheses as a temporary answer to the experimental problem. The results of the validation of the student book are presented in Table III.

TABLE III. STUDENT BOOK VALIDATION RESULT

\begin{tabular}{|l|c|c|c|}
\hline \multicolumn{1}{|c|}{ Aspects } & $\begin{array}{c}\text { Score } \\
\text { Mode }\end{array}$ & PoA (\%) & Category \\
\hline Format & 4 & 89 & Very Valid \\
\hline Content & 4 & 91 & Very Valid \\
\hline Suitability with ADI model & 4 & 89 & Very Valid \\
\hline $\begin{array}{l}\text { Suitability to train science } \\
\text { literacy }\end{array}$ & 4 & 93 & Very Valid \\
\hline Language & 4 & 93 & Very Valid \\
\hline
\end{tabular}

Based on Table III, the validation result obtained the mode score of 4 , with $89 \%$ - $93 \%$ percentage of agreement. This means that the student book compiled by researchers was categorized into very valid and reliable categories.

3) Validation Result of Student Worksheet: Student worksheets developed by the researcher oriented the ADI model used for three meetings. The worksheet is used to guide students to make it easier to understand the concept of a phenomenon about a buffer solution in everyday life. The results of the worksheets validation are presented in Table IV. 
TABLE IV. STUDENT WORKSHEETS VALIDATION RESULT

\begin{tabular}{|l|c|c|c|}
\hline \multicolumn{1}{|c|}{ Aspects } & $\begin{array}{c}\text { Score } \\
\text { Mode }\end{array}$ & PoA (\%) & Category \\
\hline Format & 4 & 89 & Very Valid \\
\hline Content & 4 & 89 & Very Valid \\
\hline Suitability with ADI model & 4 & 89 & Very Valid \\
\hline $\begin{array}{l}\text { Suitability to train science } \\
\text { literacy }\end{array}$ & 3 & 90 & Valid \\
\hline Language & 3 & 90 & Valid \\
\hline
\end{tabular}

The validation results of Student Worksheets in Table IV gets mode score between $3-4$ that was categorized into valid-very valid. So, it can be used as a teaching materials with minor revision. The percentage of agreement of the validation results was $89 \%$ - $90 \%$. This means that the assessment of the validators was reliable.

4) Validation Result of Science Literacy Tests: The assessment instrument developed in this study was a science literacy tests in the form of essay questions. This test consists of six problem descriptions in which the indicators developed are adjusted to the competence of knowledge in the buffer solutions matter. Science literacy tests are used to measure students' science literacy skills after they are trained in science literacy on buffer solutions matters taught by ADI model oriented learning. The aspects assessed in the science literacy test include content (suitability with teaching material and suitability with science literacy), and language and question writing. The results of the validation of the science literacy test are presented in Table V.

TABLE V. SCIENCE LITERACY TESTS VALIDATION RESULT
\begin{tabular}{|c|c|c|c|}
\hline \multicolumn{1}{|c|}{ Aspects } & $\begin{array}{c}\text { Score } \\
\text { Mode }\end{array}$ & PoA $(\%)$ & Category \\
\hline Content: & 4 & 95 & Very Valid \\
\hline $\begin{array}{l}\text { Suitability with } \\
\text { teaching material }\end{array}$ & 4 & 86 & Very Valid \\
\hline $\begin{array}{l}\text { Suitability with science } \\
\text { literacy }\end{array}$ & 4 & 86 & Very Valid \\
\hline Language & & &
\end{tabular}

Based on Table V, it can be seen that the validation result of science literacy tests gets mode score of 4 with very valid category. It means that the developed test can be used to assess the students' science literacy after using developed teaching materials.

\section{B. Discussion}

Teaching materials are tools, media, instructions and guidelines that will be used in the learning process. Teaching materials become a guide for teachers and students in the learning process both in the classroom, laboratory or outside the classroom. Nieveen (1999) stated that one of the three criteria of teaching materials can be said to be suitable for use in learning is valid [12]. This research aims to produce a quality, valid, and reliable teaching materials to train students' science literacy so that it can be used in the learning process. The developed teaching materials include lesson plan, student book, student worksheets, and science literacy tests.
Each teaching materials is oriented to ADI model. This learning model has eight phases, as followed (1) identification of task; (2) generation and analyze data; (3) production of a tentative argument; (4) argumentation session; (5) investigation report; (6) double-blind group peer review; (7) revise and submit the report; and (8) explicit and reflective discussion $[8,13,14]$. In the production of tentative arguments phase, students are asked to make an argument consisting of claims, evidence, and reasoning according to the results of their experiments. Students learn to determine whether the available data is relevant and convincing enough to support their claims.

In argumentation sessions, students argue. Students will learn more when they know other people's ideas, respond to questions, and convey their ideas. Reasoning is one component of the scientific argument that explains the relevance of evidence to claims submitted by linking to certain principles, concepts, or assumptions. Someone who is literate in science will use the ability of scientific reasoning when explaining how the relationship between ideas that have been made and the available evidence. This shows that there is a strong connection between argumentation and science literacy so that science literacy can be trained using the ADI Model [13].

Science literacy is the ability to respond to various natural phenomena that occur, draw conclusions based on scientific evidence found, and make decisions about nature and understand the consequences in life. There are six indicators of science literacy trained in this study, including (1) describing and applying the scientific inquiry methods in investigation, questioning, and solving problems; (2) describe procedures and experiment steps; (3) present practicum assignment correctly and accurately; (4) interpret and communicate scientific information using writing, verbal and graphic data; (5) analyze one or more relationship issues of science technology and society as well as demonstrating a scientific understanding of the application in daily life; and (6) show the explanation of natural phenomena with a logical understanding, experiment steps or applying the concept of science and technology [15].

The developed teaching materials is about buffer solutions matter. This matter is related to argumentation and science literacy because it is to invite students to think to solve a problem, develop scientific discussion through arguments, and there are applications in everyday life. Learning with this topic requires students to be active in discussions both asking and expressing opinions, and thinking about the phenomena encountered.

The validity of the developed teaching materials has gained very valid category and can be used in learning process. The validity of the lesson plan can be seen in Table II. The format aspect gets a very valid category. This is because of the time allocation, the order in which components are written, and the numbering system are correctly listed. Time allocation serves as a benchmark for the implementation of learning. The content aspect, which includes the writing of identity, core competencies (KI), basic competencies (KD), the suitability of learning indicators, suitability of learning objectives, and selection of learning models are in accordance with Permendikbud No. 22 of 2016 so that it gets a very valid category. The 
suitability of KI, KD, and indicators with the applicable 2013 curriculum will affect the learning implementation process. In addition, the suitability and clarity of learning objectives also determine whether learning is in accordance with the curriculum, material, student development, and learning steps designed in the lesson plan. Learning objectives can orient learning and students focus on what will be done. Students will know what will be learned so that in the steps of learning can be seen the effectiveness of the teaching materials developed.

Aspects of suitability with the ADI model and science literacy also get a very valid category. The learning steps in the lesson plan include teacher activities and student activities are suitable with the syntax of the ADI model. The lesson plan has also been appropriate to be used to train indicators of science literacy. The language aspect also needs to be considered in the preparation of teaching materials, the language used should be a simple language and easy to understand [16]. However, for aspects of the language, the lesson plan only gets a score mode 3 with a valid category. This is because several revisions to the sentence structure need to be done so that learning activities are studentcentered

The developed student book also gets a very valid category in all aspects. From the format aspect, there are concepts, drawings, and illustrations that have been presented coherently and suitable for buffer solutions matters. The illustrations and practice questions presented are also able to stimulate the depth of students' thinking. This student book also encourages students to look for more information because there are supporting features, such as the "Understanding Concepts" feature that helps students understand concepts. There are also other features that are suitable with the ADI model, such as presenting phenomena in advance to help students identify task and question. The "Experiment" feature helps students in the process of collecting and analyzing data associated with student worksheets. The "Mini Lab" feature encourages students to conduct experiments other than those in student worksheets. These features can be seen in Figure 1.

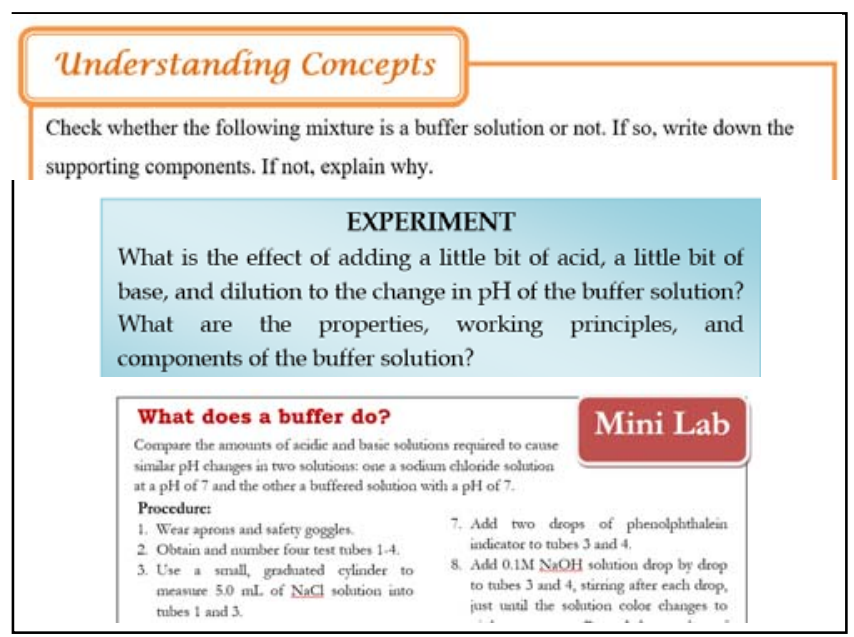

Fig 1. Features on Student Book that are Suitable with the ADI Model

The "Give Arguments" feature trains students in making scientific arguments and encouraging them to do argumentation activities (Figure. 2).

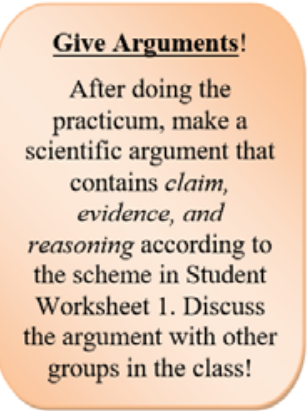

Fig 2. Features to Make Scientific Arguments

The "Chemistry around Us" and "Chemistry Info" features (Figure 3) help students understand literacy applications science related to buffer solutions in everyday life.

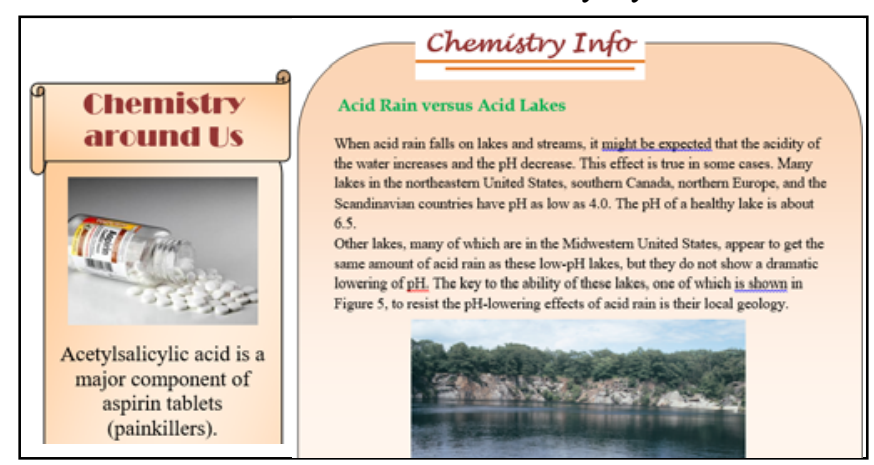

Fig 3. The "Chemistry around Us" and "Chemistry Info" Features

Overall, the student book that was developed was suitable with the ADI model and was appropriate to be used to be able to train students' science literacy, with some revisions to the addition of examples in the concept map and justification of some incorrect sentence structures

The results of the validation of student worksheets get very valid categories in the aspects of format, content, and suitability with the ADI model, as well as getting valid categories in the aspects of language and suitability with the trained science literacy. The format of the student worksheets that were developed was appropriate, interesting, and clearly stated instructions on the topics discussed. The concepts and material presented are also true and in accordance with scientific principles, as well as the steps in each activity carried out by students in suitability with the syntax of the ADI model. Learning activities in this student worksheets are adjusted to the learning phases of the ADI model, starting from phase 1 to phase 8 . Students are trained to identify problems through phenomena and formulate problems in phase 1. In phase 2, students are asked to formulate hypotheses and design experiments to answer the experiment problem. After that, students must analyze the results of the experiment and make tentative arguments consisting of claims, evidence, and reasoning, and write them down on the argumentation scheme provided in the worksheets, presented in Figure 4. 


\begin{tabular}{|l|l|}
\hline Experimental Question: & \\
\hline Claim: & Evidence: \\
\hline Rensoning: & \\
\hline
\end{tabular}

Fig 4. Argumentation Scheme in Student Worksheets

The aspect of language in student worksheets only gets a valid category because there are some sentences that are less effective and not easily understood so it needs to be revised. Likewise in the aspect of suitability with science literacy, where student worksheets are judged to only be able to properly train two indicators out of the six indicators trained, so it is necessary to review activities in student worksheets in order to be able to train indicators of science literacy as a whole. The existence of a valid student worksheets makes it easy for teachers to do the learning process for students and students can learn independently and learn to understand and carry out a written assignment. The use of student worksheets can make students actively involved in discussing the topic being studied and provide learning experiences for students in working on problems [17].

The science literacy tests validation result gets a mode score of 4 with a very valid category and the percentage of agreement is $86-95 \%$. The science literacy tests that was developed was following the buffer solutions matter. The indicators of the questions on the science literacy tests are adjusted to the basic competencies (KD) of the aspects of knowledge on the buffer solutions matter, namely to explain the working principle, calculation of $\mathrm{pH}$, and the role of buffer solutions in the body of living things. This test instrument is also suitable to the ability of science literacy that is trained in learning, in which phenomena related to buffer solutions are presented, such as the application of buffer solutions in the body of living things, in industry, and the environment. In terms of language accuracy, this instrument has also used language and sentences that are effective and suitable for students' thinking level with little revision in structure sentence, so that they are easily understood by students. It means that the developed test can be used to assess the students' science literacy after using developed teaching materials.

\section{CONCLUSION}

Based on the results of the research and discussion, it can be concluded that the teaching materials on buffer solutions matters which includes lesson plan, student book, student worksheets, and science literacy tests are very valid and reliable. The teaching materials are suitable to ADI model and can train students' science literacy. So that, the teaching materials could be used in the learning process with minor revision.

\section{ACKNOWLEDGMENT}

We thank to Mr. Achmad Lutfi, Mrs. Utiya Azizah, and Mr. Ismono from Department of Chemistry, Universitas Negeri Surabaya, for help to validate the teaching materials.

\section{REFERENCES}

[1] A.A.R.I. Sudiatmika, "Pengembangan Alat Ukur Tes Literasi Sains Siswa SMP dalam Konteks Budaya Bali”, Bandung: Disertasi , 2010.

[2] OECD, "PISA 2015 Results (Volume I): Excellence and Equity in Education", Paris: OECD Publishing, 2016.

[3] OECD, "PISA 2015: Results in Focus", Paris: OECD Publishing, 2016.

[4] OECD, "Results from PISA 2015, Country Note: Indonesia", Paris: OECD Publishing, 2016.

[5] S. Rahayu, "Mengembangkan Kemampuan Siswa dalam Menghadapi Abad 21 melalui Pembelajaran Literasi Sains". Inovasi dan Teknologi Pembelajaran Sains untuk Kemajuan Kualitas Pendidikan. Palu: Prosiding Seminar Nasional Pendidikan Sains Universitas Tadulako, 2016.

[6] C.Y. Tsai, "Promoting Science Literacy Through The Online Argumentation System", IADIS International Conference e-Learning, 2013.

[7] N. Hasnunidah, "Pembelajaran Biologi dengan Strategi ArgumentDriven Inquiry dan Keterampilan Argumentasi Peserta Didik", Jurnal Pendidikan Biologi Vol. 5 No. 1., 2013.

[8] V. Sampson, J. Grooms, and J. Walker, “Argument-Driven-Inquiry: A Way to Promote Learning During Laboratory Activities", The Science Teacher, 2009.

[9] S. Thiagarajan, D. Semmel, and M. Semmel, "Instructional Development for Training Teachers of Expectional Children", Minneapolis: Leader Training Institute/Special Education Universitas of Minnesota, 1974.

[10] G.T. Ratumanan and T. Laurens, "Evaluasi Hasil Belajar yang Relevan dengan Memecahkan Problematika Belajar dan Mengajar", Bandung: Alfabeta, 2006.

[11] G.D. Borich, "Observation Skill for Effective Teaching”, USA: Macmilan Publishing Company, 1994.

[12] N. Nieveen, "Prototyping to Reach Product Quality", Dordrecht: Kluwer Academic Publisher, 1999.

[13] V. Sampson, J. Grooms, and J. Walker, "Argument-Driven Inquiry as a Way to Help Students Learn How to Participate in Scientific Argumentation and Craft Written Arguments: An Exploratory Study", Science Education, 2011, pp. 217 - 257. DOI: 10.1002/sce.20421.

[14] V. Sampson, P. Enderle, and J. Grooms, "Argumentation in Science Education", The Science Teacher, 2013, DOI: 10.2505/4/tst13_080_05_30.

[15] M.I.S. Putra, W. Widodo, and B. Jatmiko, "The Development of Guided Inquiry Science Teaching Materials to Improve Science Literacy Skill of Prospective MI Teachers", Jurnal Pendidikan IPA Indonesia (JPII), 2016, Vol. 5 No. 1, pp. 83-93.

[16] N. Maiasputri, Lufri, Y. Ahda, and R. Sumarmin, "The Validity of the Development of Project-Based Oriented Learning Modules on Evolution and Biotechnology Materials for High School", International Journal of Progressive Sciences and Technologies (IJPSAT), 2018, Vol. 6 No. 2, pp. 433-43.

[17] A. Majid, "Perencanaan Pembelajaran", Bandung: Remaja Rosdakarya, 2011. 